\title{
Cranial bone collapse in microcephalic infants prenatally exposed to Zika virus infection
}

Figure $1 \quad$ Axial CT
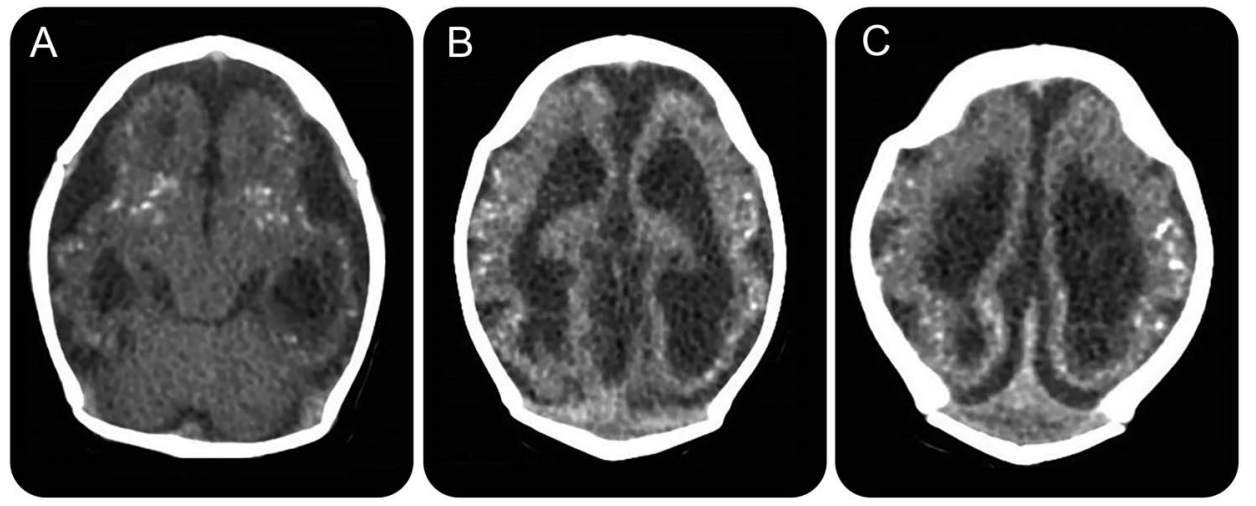

(A-C) Severe brain abnormalities are being observed in infants prenatally exposed to Zika virus infection. The image illustrates a repeating pattern among these patients: cerebral atrophy, pachygyria, lissencephaly, parenchymal calcifications, and ex vacuum hydrocephalus.

Brazil has been experiencing an outbreak of Zika virus, a flavivirus transmitted by Aedes mosquitoes. Since October 2015, more than 4,000 infants, ${ }^{1}$ born to mothers suspected to have contracted this infection during pregnancy, have microcephaly ${ }^{1,2}$ and CNS malformations (figure 1), including parenchymal and periventricular calcifications, ventriculomegaly, and cortical migration anomalies. ${ }^{2}$ This suggests marked viral neurotropism. Upon performing CT, cranial malformations (figure 2) with a pointed occiput are also observed.

We hypothesize that the extensive brain destruction may lead to collapse of the upper cranial bones over the occiput, pushing it backwards, causing this peculiar malformation.

Dafne Dain Gandelman Horovitz, MD, PhD, Marcos Vinicius da Silva Pone, MD, MS, Sheila Moura Pone, MD, PhD, Tania Regina Dias Saad Salles, MD, PhD,

Marcia Cristina Bastos Boechat, MD, PhD

From the National Institute of Women, Children, and Adolescents Health Fernandes Figueira (IFF)-Fundação Oswaldo Cruz (Fiocruz), Rio de Janeiro, Brazil.

Author contributions: D.D.G. Horovitz: corresponding author, saw and examined patients, searched literature and wrote manuscript. M.V.S. Pone, S.M. Pone, and T.R.D.S. Saad: authors, saw and examined patients, revised and discussed examination findings, and revised manuscript. M.C.B. Boechat: performed and described imaging studies, discussed examination findings, selected and prepared images for manuscript, and revised manuscript.

Study funding: No targeted funding reported.

Disclosure: The authors report no disclosures relevant to the manuscript. Go to Neurology.org for full disclosures.

Correspondence to Dr. Gandelman Horovitz: dafne@iff.fiocruz.br

1. Brasil Ministério da Saúde. Centro de Operaçôes de Emergências em Saúde Pública sobre Microcefalias: Monitoramento de Casos de Microcefalia no Brasil. Informe Epidemiológico 13-Semana Epidemiológica 06/2016 (07 a 13/02/2016) Brasília: Ministério da Saúde, 2016 (in Portuguese). Available at: http://combateaedes.saude.gov.br/images/pdf/Microcefalias_Informe_ Epidemiologico_13_SE_06_2016_17fev2016.pdf. Accessed February 24, 2014.

2. Schuler-Faccini L, Ribeiro EM, Feitosa IM, et al. Possible association between Zika virus infection and microcephaly: Brazil, 2015. MMWR Morb Mortal Wkly Rep 2016;65:59-62. 


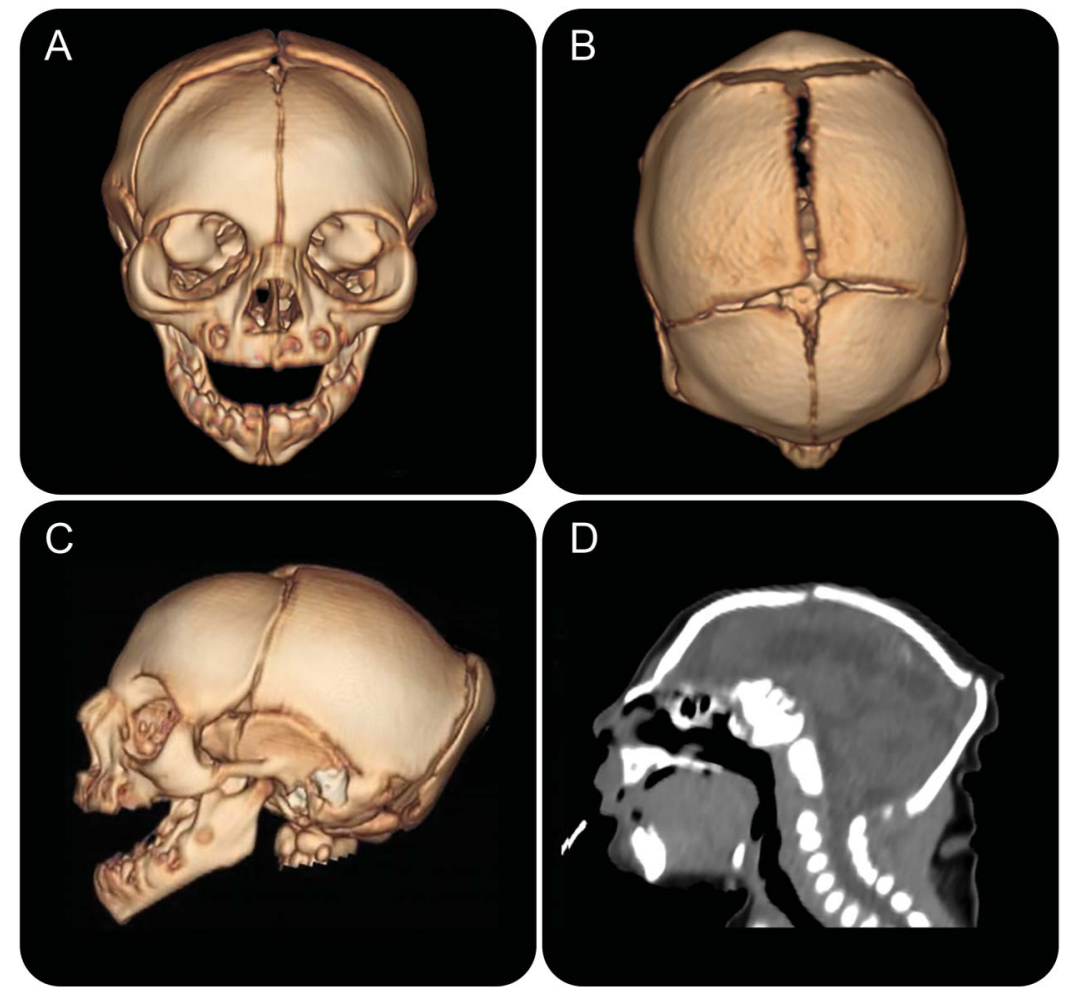

Anterior (A), superior (B), and lateral (C) views show significant microcephaly, small anterior fontanelle, and occipital protrusion in infant whose mother had infection compatible with Zika virus in the first trimester of pregnancy. (D) Sagittal CT shows redundant scalp and cutaneous folds in the occipital region.

\section{Subspecialty Alerts by E-mail!}

Customize your online journal experience by signing up for e-mail alerts related to your subspecialty or area of interest. Access this free service by visiting Neurology.org/site/subscriptions/etoc.xhtml or click on the "E-mail Alerts" link on the home page. An extensive list of subspecialties, methods, and study design choices will be available for you to choose from—allowing you priority alerts to cutting-edge research in your field!

\section{Get Your Front Row Seat to the Premier Event on Sports Concussion}

The world's leading experts on sports concussion are once again hosting the year's premier event on sports concussion. The American Academy of Neurology's 2016 Sports Concussion Conference, set for July 8 through 10 in Chicago, features a concussion boot camp and is poised to be the go-to meeting for all disciplines involved in the prevention, diagnosis, and treatment of professional, collegiate, and high school sports concussion, including neurologists, athletic trainers, and other medical professionals. 


\title{
Neurology
}

\author{
Cranial bone collapse in microcephalic infants prenatally exposed to Zika virus \\ infection \\ Dafne Dain Gandelman Horovitz, Marcos Vinicius da Silva Pone, Sheila Moura Pone, et al. \\ Neurology 2016;87;118-119 \\ DOI 10.1212/WNL.0000000000002814
}

\section{This information is current as of July 4, 2016}

\section{Updated Information \& Services}

References

Citations

Subspecialty Collections

Permissions \& Licensing

Reprints including high resolution figures, can be found at: http://n.neurology.org/content/87/1/118.full

This article cites 1 articles, 0 of which you can access for free at: http://n.neurology.org/content/87/1/118.full\#ref-list-1

This article has been cited by 1 HighWire-hosted articles: http://n.neurology.org/content/87/1/118.full\#\#otherarticles

This article, along with others on similar topics, appears in the following collection(s):

\section{CT}

http://n.neurology.org/cgi/collection/ct

Neonatal

http://n.neurology.org/cgi/collection/neonatal

Public health

http://n.neurology.org/cgi/collection/public_health

Viral infections

http://n.neurology.org/cgi/collection/viral_infections

Information about reproducing this article in parts (figures,tables) or in its entirety can be found online at:

http://www.neurology.org/about/about_the_journal\#permissions

Information about ordering reprints can be found online:

http://n.neurology.org/subscribers/advertise

Neurology ${ }^{\circledR}$ is the official journal of the American Academy of Neurology. Published continuously since 1951, it is now a weekly with 48 issues per year. Copyright @ 2016 American Academy of Neurology. All rights reserved. Print ISSN: 0028-3878. Online ISSN: 1526-632X.

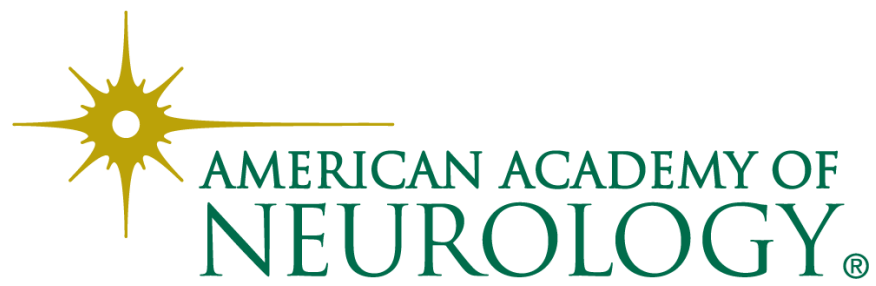

